\section{THE RECENT RACE OF AUTO-MOBILE CARRIAGES IN FRANCE.}

I AST month a most interesting race of auto-mobile L carriages took place in France. The course taken was from Versailles to Bordeaux, and then back to Paris. June I I was fixed for the day of starting, and forty-six carriages were to have taken part in the race, but only twenty-eight arrived in time, twenty-two of these taking active part, and nine performing the journey within

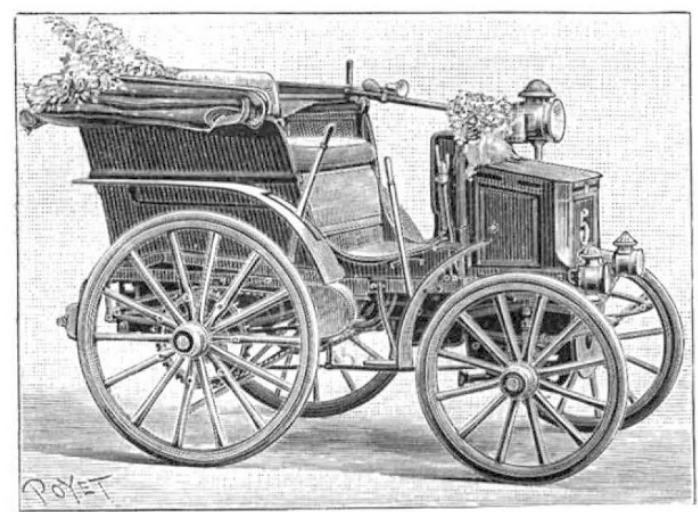

Fig. x.-No. 5. MM. Panhard and Levassor's carriage, worked by gazoline, and to seat two persons (2nd prize, 12,600 francs). Arrived June 13 , at I2.57 a.m.

a hundred hours; eight of the latter were worked by petroleum or "gazoline," and one by stearn.

The accompanying illustrations, which we are enabled to reproduce by the courtesy of the Editor of La Nature, are from photographs taken at the exhibition of the carriages on their return. No. 5 (Fig. I) is the one which was the first to arrive back in Paris. It received the second prize, for it only seats two persons, and a regulation had been made, that no carriage seating less than four persons could receive the first. No. 16 (Fig. 2)

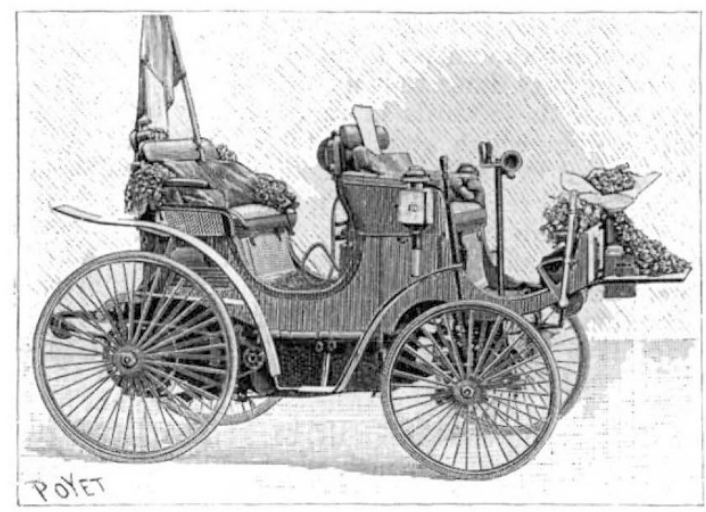

FrG. 2.-No. 16. MM. Peugeot's phaeton, worked by gazoline, and to seat four persons (ist prize, 31,500 francs). Arrived June 14, at 12.2 a.m.

really came in fourth, but received the first prize, for on reckoning up the time taken in the journey, it was found to be two minutes less than that taken by No. 8. The third prize was won by No. 15 (Fig. 3).

Taking all the facts into consideration, it appears that the lighter carriages travelled best. This proves the advantage of using petroleum or gazoline, for in order to produce one horse-power it requires per hour $\mathrm{I}_{144} \mathrm{lbs}$. of gazoline, whereas, if it were worked by steam, at least $6 \%$ lbs. of coal and $39 \frac{4}{5}$ lbs. of water would be necessary per hour, and if worked by electricity, there would have to be accumulators of the weight of $220 \mathrm{lbs}$.

Light carriages have many advantages, for besides having to be less careful about the weight of fuel, they can also have lighter constructed wheels. M. Michelin's carriage, with pneumatic tyres, went the whole distance without an accident, whereas the steam vehicles, one and all, had mishaps, owing almost always to their great weight.

It would take up much time and space to relate the many incidents which occurred; suffice it to say that, apart from ordinary breakdowns, in some towns the travellers were hindered by the inhabitants, in others they were enthusiastically peited with flowers.

These auto-mobile machines are evidently the carriages of the future. According to the Times of July Io, a journey has quite recently been performed in our own country by the Hon. Evelyn Ellis, who was accompanied by Mr. T. R. Simms, managing director of the Daimler Motor Syndicate. The carriage is a four-wheeled dogcart, and will hold four persons, with room also for two portmanteaus. It was built by Messrs. Panhard and Levassor, of Paris, and is worked by petroleum, the cost

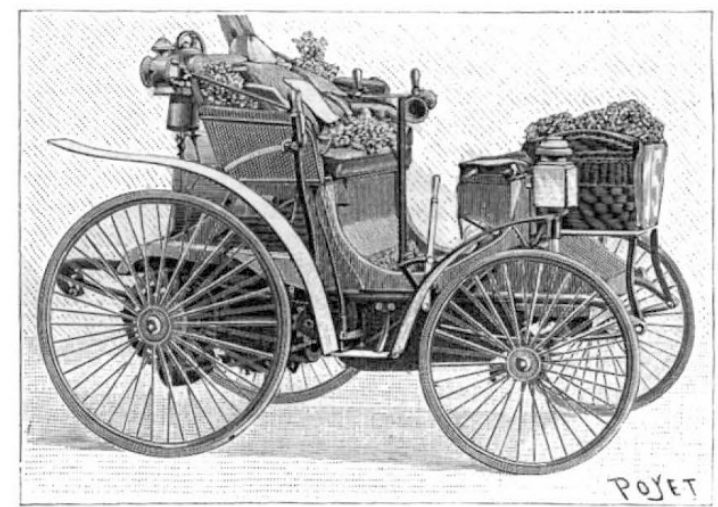

FIG. 3.-No. 15. Worked by gazoline, to seat two persons. Belonging to the sons of Peugeot Brothers (3rd prize, 6300 francs). Arrived June 13, at 6.37 p.m.

being about a halfpenny an hour. The journey undertaken by Mr. Ellis, a distance of fifty-six miles, was performed in five hours and a half.

We understand that the proprietors of the Engineer are offering a prize of $£, 1000$ to the maker of the fastest going motor.

W.

\section{NOTES.}

WE regret to notice that Prof. C. C. Babington, F.R.S., Professor of Botany in the University of Cambridge, died on Monday morning, at the age of eighty-six.

Prof. Ramsay has been elected a Correspondant of the Paris Academy of Sciences, in the Section of Chemistry, and M. Sabatier has been elected a Correspondant of the Section of Anatomy and Zoology.

Mr. H. J. Chaney, of the Standards Department, Board of Trade, will attend the Sexennial Conference of the International Committee on Weights and Measures at Paris, on September 6 next, as the representative of Her Majesty's Government.

Dr. CARL Barus, of the Smithsonian Institution, has, says Sience, accepted the Hazard Professorship of Physics in Brown University. It is stated that Brown University has recently spent $£ 20,000$ in the building and equipment of a physica laboratory.

No. I 343 , VOL. 52 ] 